\title{
Chemical composition and medicinal potentials of the bark of Erythrophleum ivorense A. Chev
}

\author{
R. O. Ogboru*, L. O. Akideno and E. A. Owoeye \\ Forestry Research Institute of Nigeria, Moist Forest Zonal Research Station, P. M. B 2444, Benin-city, Edo- State, Nigeria. \\ *Corresponding author. Email: rachov44@gmail.com, rachov44@yahoo.com
}

Copyright (C) 2017 Ogboru et al. This article remains permanently open access under the terms of the Creative Commons Attribution License 4.0, which permits unrestricted use, distribution, and reproduction in any medium, provided the original work is properly cited.

Received 3rd February, 2017; Accepted 20th March, 2017

\begin{abstract}
Determination of the chemical composition of the bark of Erythrophleum ivorense A.chev showed some proximate compounds such carbohydrates, protein, lipids and vitamin C, and not absent in essential food fibre. Essential minerals of sodium, phosphorus, iron, copper and zinc in contents levels needed for a healthy life, except sodium, with a very high content level hence should be diluted properly when administered as a laxative. Some phytochemicals such as phenols, steroids, tannins, flavanoids, alkaloids, saponin and cadiac glycosides were present which gives credence to the medicinal benefits of the bark of the wood despite it wide timber used for construction and toxic nature.
\end{abstract}

Key words: Erythrophleum ivorense bark, phytochemical screening, proximate content, mineral elements, total antioxidant capacity.

\section{INTRODUCTION}

The role of forest in our atmosphere cannot be over emphasized. The necessity to study forest plant species according to WHO (2001) was based on extensive use of plant portions in folk medicine and offered a basis for the daily living of the people. A large number of African indigenous trees species have been recognized to have health defensive properties and uses (Okeno et al., 2003; Einosho and Ayorinde, 2008). Erythrophlem ivorense belongs to the family Caesalpiniacae (LeguminosaeCaesalpinioideae) and is found majorly in the Gambia to the Central African Republic and Garbon. The timber of Erythrophleum Ivorense in Nigeria, is marketed as 'Iyin' in Edo, 'erun' in yoruba and 'ihi' in Igbo (Aigbokhan, 2014). It is called 'Ordeal tree', 'missanda', 'alu', 'bolondo', 'Sasswood tree'(English). Lim du Gabon, Tali (France) and Mancone (Italian) aroundparts of Africa where it is found (Burkill, 1985). Some species of plant in the Erythrophleum genus are also identified to be venomous and toxic to some livestock. The bark of Erythrophleum ivorense traded as 'sassy-bark', 'man cona bark', 'casca bark' or 'ecorce de tali' and has several medicinal uses (ITTO, 2004). Bark extracts of Erythrophleum ivorense are taken orally in Sierra Leone as an emetic and purgative and is applied externally to relieve pain (Richter and Dallwitz, 2000). According to Betti (2004), it is taken orally as a laxative and outwardly to relieve pains. In IvoryCoast, extract from young branches of crushed Erythrophleum ivorense is rubbed on skin to treat chicken pox (PROTA1, 2008). The bark and occasionally the seeds are widely used as hunting and ordeal poison (Barkarr and Janos, 1996). In Liberia and Garbon, the bark of Erythrophleum ivorense is preferred to that of Erythrophleum suaveolens (Bosch et al., 1996). Erythrophleum ivorense occurs scattered in evergreen primary and secondary forest and moist semi-deciduous forest (Diabate et al. 2005). It has been classified as a non-pioneer light demander. Seedlings are often found in smaller forest gaps. Erythrophleum ivorense can be propagated in the nursery as its seeds take three weeks to germinate. The bark is also used as fish poison in Sierra Leone (PROTA, 2008). The wood is quite hard and hefty and suitable for woodwork, flooring, rail way sleepers, harbor and dock work, turnery, bridges and constructions. It is also used for boat building and wheel hubs. It makes excellent charcoal and good firewood. In Seirra-Leone and Ivory Coast the bark is used for tanning (PROTA, 2008). A bark decoction added to fermenting palm wine would make it a more potent drink (Voorhoeve, 1979). In trade 
statistics, Erythrophleum ivorense is regarded as the fourth most important timber of Cameroon and was imported to China in 2005 (PROTA, 2008). It is an evergreen tree that can grow up to 40 metres tall, bole cylindrical but sometimes fluted at base with or without buttresses. Its leaves are alternate and flowers are bisexual. The toxicological nature of the specie has been reported by Amoah et al. (2014). They worked on methanol extract on the bark and were administered to rats which caused an increase inflammatory in the liver and kidney of the rats. The phytochemical screening of the plant also revealed the presence of alkaloids, tannins, flavonoids, steroids, cardiac glycosides and terpenoids but they were not quantified. Also Sima et al. (2016) worked on phytochemical screening identifying the phytochemicals, antioxidant and antimicrobial properties of the bark of Erthrophleum ivorense A. Chev. Hence, this research work quantified the exact amount of the phytochemicals present contained in the bark Erythrophleum ivorense and the proximate analysis to show if it is fit for consumption. This study therefore attempts to identify the chemical compositions contained in the bark of Erythrophleum ivorense through proximate analysis, phytochemical screening, mineral analysis and total antioxidant capacity.

\section{MATERIALS AND METHODS}

\section{Collection of plant samples}

Bark samples of Erythrophleum ivorense A. Chev were obtained from the Federal Department of Forestry, Benin City, Edo State, Nigeria in October, 2016. It was authenticated by Mr Emmanuel Isebemhe, the taxonomist of the moist Forest Research station. The Bark sample was air-dried for one month at the research station, Benin City and pulverized to powder and sent to the Delta State University Chemistry Laboratory in Abraka for the chemical analysis.

\section{Preparation of aqueous extract of plant samples}

The aqueous extract of bark of Erythrophleum ivorense sample was primed by soaking $10 \mathrm{~g}$ of powdered samples in $200 \mathrm{ml}$ of distilled water for 12 hours. The extracts were tried for carotenoids, terpenoids, alkaloids, tannins, flavanoids, saponin, cardiac glycoside, anthraquinone, phenols, polyphenols and steroids

\section{Phytochemical analysis}

Biochemical tests were conducted on the aqueous extract of the bark sample by using standard methods adopted by Sofowora (1993), Harbone (1973), Oyoyede (2005), Ogboru et al. (2015) and Owoeye et al. (2016).

\section{Qualitative analysis on phytochemical constituents}

\section{Test for tannins}

$0.5 \mathrm{~g}$ of powdered sample was boiled in $20 \mathrm{ml}$ of distilled water in a test tube and then filtered. The filtration method used here is the normal method, which includes a conical flask and filter paper. $0.1 \%$ of $\mathrm{FeCl}_{2}$ was added to the filtrate and observed for brownish green or a blue black coloration, which shows the presence of tannins.

\section{Test for saponins}

$2 \mathrm{~g}$ of powdered bark sample was boiled together with 20 $\mathrm{ml}$ of distilled water in a water bath and filtered. $10 \mathrm{ml}$ of the filtrate was mixed with $5 \mathrm{ml}$ of distilled water in a test tube and shaken vigorously to obtain a stable persistent froth. The frothing was then mixed with 3 drops of olive oil and observed for the formation of emulsion, which indicates the presence of saponins.

\section{Test for flavonoids}

A few drops of $1 \% \mathrm{NH}_{3}$ solution was added to the aqueous extract of the bark sample in a test tube. A yellow coloration was seen indicating flavonoids compounds was present.

\section{Test for cardiac glycosides}

$1 \mathrm{ml}$ of concentrated $\mathrm{H}_{2} \mathrm{SO} 4$ was prepared in a test tube. 5 $\mathrm{ml}$ of aqueous extract from the bark sample was mixed with $2 \mathrm{ml}$ of glacial $\mathrm{CH}_{3} \mathrm{CO}_{2} \mathrm{H}$ containing 1 drop of $\mathrm{FeCl}_{3}$. The above mixture was carefully added to the $1 \mathrm{ml}$ of concentrated $\mathrm{H}_{2} \mathrm{SO} 4$ so that the concentrated $\mathrm{H}_{2} \mathrm{SO}_{4}$ was underneath the mixture. A brown ring appeared, indicating the presence of the cardiac constituent.

\section{Test for phenols}

To $3 \mathrm{ml}$ of extract, $3 \mathrm{ml}$ of lead acetate solution was added. The occurence of white precipitates indicates the presence of phenols.

\section{Test for alkaloids}

To $3 \mathrm{ml}$ of filterate, $1 \mathrm{ml}$ of Hagers reagent (Saturated picric acid solution) was added. The appearance of yellow precipitate shows alkaloids present.

\section{Test for steroids}

$2 \mathrm{ml}$ of acetic anhydride was added to $0.5 \mathrm{~g}$ extract with 2 $\mathrm{ml}$ of sulphuric acid and observes for the colour change 
from violet to blue or green in samples indicating the presence of steroids.

\section{Test for terpenes}

$0.5 \mathrm{~g}$ of plant extract in a test tube was added with $2 \mathrm{ml}$ of chloroform and $5 \mathrm{ml}$ of concentrated sulphuric acid carefully. A reddish brown interface to show positive result for terpenes.

\section{Test for anthraquinones}

$0.5 \mathrm{~g}$ of plant extract is shaken with $10 \mathrm{ml}$ of benzene and filtered. $5 \mathrm{ml}$ of $10 \%$ ammonia is added to the filterate. The mixture is shaken and the presence of pink, red or violet colour indicates the presence of anthraquinones.

\section{Quantitative analysis on phytochemical constituents}

\section{Phenols}

The quantity of phenols was determined using the spectrophotometer method. The fat free plant sample was boiled with $50 \mathrm{ml}$ of Ether $\left.\left(\mathrm{CH}_{3} \mathrm{CH}_{2}\right)_{2} \mathrm{O}\right)$ for 15 mins. $5 \mathrm{ml}$ of the boiled sample was then pipette into $50 \mathrm{ml}$ flask, and 10 $\mathrm{ml}$ of distilled water was added. After the addition of distilled water, $2 \mathrm{ml}$ of $\mathrm{NH}_{4} \mathrm{OH}$ solution and $5 \mathrm{ml}$ of concentrated $\mathrm{CH}_{3}\left(\mathrm{CH}_{2}\right) \mathrm{CH}_{2} \mathrm{OH}$ was added to the mixture. The sample was made up to the mark and left for 30 mins to react for colour development and measured at $505 \mathrm{~nm}$ wavelength using a spectrophotometer.

\section{Cardiac glycosides}

The Baljets reagent method was used $(95 \mathrm{ml}$ of $1 \%$ picric acid $+5 \mathrm{ml}$ of $10 \% \mathrm{NaOH}$ ). $1 \mathrm{~g}$ of powdered sample was soaked overnight with $70 \%$ ethanol and filtered. The extract was purified by lead acetate and $\mathrm{Na}_{2} \mathrm{HPO}_{4}$ and $1 \mathrm{ml}$ of freshly prepared Baljets reagent was added. The solution was put in the curvette and read at $495 \mathrm{~nm}$ in the UV spectrophotometer.

\section{Alkaloids}

$5 \mathrm{~g}$ of plant sample was prepared in a beaker and $200 \mathrm{ml}$ of $10 \% \mathrm{CH}_{3} \mathrm{CO}_{2} \mathrm{H}$ in $\mathrm{C}_{2} \mathrm{H}_{5} \mathrm{OH}$ was added to the powdered plant sample. The mixture was covered and allowed to stand for four hours. The mixture was then filtered and the extract was allowed to become concentrated in a water bath until it reaches $1 / 4$ of the original volume. Concentrated $\mathrm{NH}_{4} \mathrm{OH}$ is added until the precipitation is complete. The whole solution is allowed to settle and the precipitate was collected and washed with dilute $\mathrm{NH}_{4} \mathrm{OH}$ and then filtered. The residue is alkaloid which is then dried and weighed.

\section{Tannins}

Quantity of tannins was determined by using the spectrophotometer method. $0.5 \mathrm{~g}$ of plant sample is weighed into a $50 \mathrm{ml}$ plastic bottle. $50 \mathrm{ml}$ of distilled water is added and stirred for 1 hour. The sample is filtered into a $50 \mathrm{ml}$ volumentric flask and made up to mark. $5 \mathrm{ml}$ of the filtered sample is then pipette out into test tube and mixed with $2 \mathrm{ml}$ of $0.1 \mathrm{M} \mathrm{FeCL}_{3}$ in $0.1 \mathrm{M} \mathrm{HCl}$ and $0.008 \mathrm{MK}_{4} \mathrm{Fe}(\mathrm{CN})_{6} .3 \mathrm{H}_{2} \mathrm{O}$. The absorbance is measured with a spectrophotometer at $395 \mathrm{~nm}$ wavelength within 10 mins.

\section{Saponins}

$20 \mathrm{~g}$ of powdered back of plant sample was put in a cornical flask and $100 \mathrm{ml}$ of $20 \% \mathrm{C}_{2} \mathrm{H}_{5} \mathrm{OH}$ was added to the plant sample. The sample was heated over a hot bath for 4 hours with continous stiring at about $55^{\circ} \mathrm{C}$. The mixture was then filtered and the residue re-extracted with another $200 \mathrm{ml}$ of $20 \% \mathrm{C}_{2} \mathrm{H}_{5} \mathrm{OH}$. The combined extracts were reduced to $40 \mathrm{ml}$ over a water bath at about $90^{\circ} \mathrm{C}$. The concentrated solution was then transferred into a 250 $\mathrm{ml}$ separator funnel and $20 \mathrm{ml}$ of $\left(\mathrm{CH}_{3} \mathrm{CH}_{2}\right) 2 \mathrm{O}$ was added to the extract and shaken vigorously. The aqueous layer was recovered while the $\left(\mathrm{CH}_{3} \mathrm{CH}_{2}\right)_{2} \mathrm{O}$ layer was discarded and the purification process was repeated twice. $60 \mathrm{ml}$ of $\mathrm{n}-\mathrm{C}_{4} \mathrm{H}_{9} \mathrm{OH}$ was added and the combined $\mathrm{n}-\mathrm{C}_{4} \mathrm{H}_{9} \mathrm{OH}$ extracts was washed twice with $10 \mathrm{ml}$ of $5 \% \mathrm{Nacl}$. The remaining solution was then heated in a water bath and allowed to evaporation. After the evaporation, the samples were dried in the oven to a constant weight.

\section{Flavonoids}

$10 \mathrm{~g}$ of the plant sample was repeatedly extracted with 100 $\mathrm{ml}$ of $80 \%$ aqueous methanol at room temperature. The entire solution was then filtered through filter paper and the filterate was transferred into a water bath and the solution was evaporated into dryness. The sample was then weighed until a constant weight was obtained.

\section{Proximate composition determinations}

The proximate composition of the bark of Erythrophleum ivorense A.Chev was determined using the methods of the AOAC (1990). These analysis included carbohydrate, crude protein, moisture content, ash, crude fibre, fat and vitamin $\mathrm{C}$.

\section{Antioxidant analysis}

Total Antioxidant capacity was determined by the Phospho-molybdenum method according to the procedure 
Table 1. Phytochemistry.

\begin{tabular}{lcc}
\hline Phytochemicals & Qualitative Remarks & Quantitative remarks(mg/kg) \\
\hline Tannin & + & $31.17 \pm 0.04$ \\
Flavanoid & + & $33.76 \pm 0.25$ \\
Alkaloid & + & $58.89_{ \pm} 0.20$ \\
Saponin & + & $41.63_{ \pm} 0.11$ \\
Cardiac glycoside & + & $37.45_{ \pm} 0.16$ \\
Anthraquinon & - & - \\
Phenolic & + & $10.08_{ \pm} 0.38$ \\
Terpenes & - & - \\
Carotenoid & - & - \\
Steriods & + & $06.03_{ \pm 0.02}$ \\
\hline
\end{tabular}

(+) Present (-) Absent.

described by Prieto et al. (1991). This was also adopted by Vernon et al. (1999), Zongo et al. (2010) and Ogboru et al. (2016). Total Phenols were determined using the method described by Obadoni and Ochuko (2001). For the extraction of phenolic content, the fat free sample was boiled with $50 \mathrm{ml}$ of ether for 15 mins. $5 \mathrm{ml}$ of the extract was pipette into a $50 \mathrm{ml}$ volumetric flask and then $10 \mathrm{ml}$ of distilled water was added. The samples were made up to the mark and left to react for 30 mins for colour development. The absorbance at $505 \mathrm{~nm}$ was read at a UV-spectrophotometer.

\section{Mineral element analysis}

Milled samples $(5 \mathrm{~g})$ were burnt to ash in a furnace at $550^{\circ} \mathrm{C}$ for 24 hours. The resulting ash was cooled in a desiccator and weighed. $2 \mathrm{ml}$ of Concentrated $\mathrm{HCl}$ was added to melt the ash and a few drops of $\mathrm{HNO}_{3}$ were added (AOAC, 1990). The solution was placed in a steaming water bath and evaporated almost to dryness. The contents were transferred to $100 \mathrm{ml}$ volumetric flask and diluted to volume with distilled water and appropriate dilutions were made for each element before analysis.

\section{Determination of Sodium ( $\mathrm{Na}$ ) and Phosphorus $(\mathrm{P})$ by flame photometer Principle}

The flame photometer emits radiant energy when atoms of an element arrival to their ground state after their excitation by the high temperature of the flame. The degree of emission is related to the concentration of the element in the solution. $\mathrm{Na}$ and $\mathrm{K}$ analysis of the sample were done by the method of flame photometry.

\section{Determination of Iron (Fe), Zinc (Zn) and Copper (Cu)}

The same wet sample solutions of the bark of Erthrophleum ivorense was analyzed for the determination of Iron content, Zinc and Copper using the Atomic absorption spectrophotometer with Model Agilent technologies 55A. Different electrode lamps were used for each mineral. The equipment was run for standard solutions of each mineral before and during determination to check that it is working properly. The dilution factor was 100.

\section{RESULTS AND DISCUSSION}

\section{Phytochemistry}

The phytochemical screening of the bark of Erythrophleum ivorense which was sourced from Federal Department of Forestry, Benin City, revealed that alkaloids (53.89 \pm $0.20 \mathrm{mg} / \mathrm{kg}$ ), Phenolic compounds (10.08 $\pm 0.38 \mathrm{mg} / \mathrm{kg})$, Flavanoids (33.76 $\pm 0.25 \mathrm{mg} / \mathrm{kg})$, Tannins $(31.17 \pm 0.04$ $\mathrm{mg} / \mathrm{kg})$, Saponins $(41.63 \pm 0.11 \mathrm{mg} / \mathrm{kg})$, Cardiac glycosides $(37.45 \pm 0.16 \mathrm{mg} / \mathrm{kg})$ and steroids $(06.03 \pm 0.02$ $\mathrm{mg} / \mathrm{kg}$ ) were significantly present in the sample (Table 1 ).

Erythrophleum alkaloids have similar pharmacological activities as digitoxine and ouabain which have shown to have anti-hypersentive effects, antiarrhythmic effect, antimalarial activity and anticancer actions (PROTA, 2008).

Anthraquinones and steroids constituents promote the plant in the treatment and therapeutic applications as arrow poisons or cardiac drugs as laxatives. The presence of anthraquinones was reported to have anti-oxidant, antimicrobial, anti-viral, anti-malaria and anti-tumor activities. The presence of alkaloids also indicates that the bark of Erythrophleum ivorense can be use as muscle relaxant in clinics. The presence of flavonoids in a plant indicates its anti-allergic, anti-inflammatory, anti-cancer, anti-oxidantand hypo-lipidemic effects (Skene and Sutton, 2006). Flavanoids have also been reported to be potent antioxidant and free radicals scavengers capable of protecting cell membranes from damage (Noda et al., 2000)

Tannins are used in the dyestuff productions as caustics for cationic dyes (tannin dyes) and also inks (iron gallate 
Table 2. Proximate Analysis.

\begin{tabular}{lc}
\hline Parameters & $\mathbf{M g} / \mathbf{k g}$ \\
\hline Carbohydrates & $57.61 \pm 0.08$ \\
Protein & $201.47 \pm 0.02$ \\
Moisture content & $4.38 \pm 0.16$ \\
Ash & $63.11 \pm 0.38$ \\
Fibre & $130.84 \pm 0.04$ \\
Fat & $0.02 \pm 1.16$ \\
Vitamin C & $8.06 \pm 0.20$ \\
\hline
\end{tabular}

Table 3. Mineral Analysis.

\begin{tabular}{lc}
\hline Mineral elements & (ppm) \\
\hline Zinc & $21.66 \pm 0.02$ \\
Copper & $3.77 \pm 0.05$ \\
Sodium & $214.53 \pm 0.04$ \\
Iron & $42.24 \pm 0.14$ \\
Phosphorus & $2.143 \pm 0.01$ \\
\hline
\end{tabular}

Table 4. Antioxidant Analysis.

\begin{tabular}{lc}
\hline Parameters & Values \\
\hline Total Phenolic (GAE100-1) & $10.08 \pm 0.03$ \\
Vitamin C (mg/kg) & $8.06 \pm 0.09$ \\
Total Antioxidant Capacity mg/Vce & $63.38 \pm 0.10$ \\
\hline
\end{tabular}

ink). In the food industries tannins are used to clarify wines, beer and fruit juices. It can also be used as coagulants in rubber production (Gyamfi and Aniya, 2002). Lately, tannins have enticed scientific attention, especially due to amplified incidence of deadly illnesses such as various cancer and AIDS. Tannin rich medicinal plants are used to heal a lot of illnesses; such as leucorrhoea, rhinorrhea and diarrhea. The presence of a few phytochemicals gives belief to the medicinal benefits that the bark of this plant encompasses.

\section{Proximate analysis}

Proximate study revealed that the bark contains little nutrients and minerals. Macro nutrient like protein and Carbohydrates were determined with value of $201.47 \pm$ 0.02 and $57.61 \pm 0.08 \mathrm{mg} / \mathrm{kg}$ respectively. Other macro nutrients were also relatively high in content level. Crude Lipid had a small content level of $0.02 \pm 01.16 \mathrm{mg} / \mathrm{kg}$. Proximate analysis for crude Fibre, Vitamin C, Ash, and Moisture also revealed their contents levels to be $130.84 \pm$ $0.04,8.06 \pm 0.02,52.37 \pm 0.38$ and $4.38 \pm 0.16 \mathrm{mg} / \mathrm{kg}$ respectively (Table 2 ).

\section{Mineral analysis}

The existence of essential minerals and their contents levels analyzed showed that Erythrophleum ivorense contains sodium $(\mathrm{Na} ; 214.53 \pm 0.04) \mathrm{mg} / \mathrm{kg}$, phosphorus $(\mathrm{P} ; 2.143 \pm 0.01) \mathrm{mg} / \mathrm{kg}$, Iron (Fe; $17.42 .24 \pm 0.02) \mathrm{mg} / \mathrm{kg}$, Zinc $(\mathrm{Zn} ; 21.66 \pm 0.02) \mathrm{mg} / \mathrm{kg}$ and Copper $(\mathrm{Cu} ; 3.77 \pm$ $0.05) \mathrm{mg} / \mathrm{kg}$ respectively (Table 3 ). The values ranges are non-lethal, therapeutic and idea for the maintenance of good health except for sodium that was on the very high side.

\section{Total antioxidant analysis}

Erythrophleum ivorense bark was found to be very opulent in anti-oxidants and phenols with total anti-oxidant capacity of $63.38 .02 \pm 0.12 \mathrm{mgVce}$ and phenol total content of $10.08 \pm 0.03$ GAE100-1 $^{-1}$ (Table 4). Total Anti-oxidant Capacity in Erythrophleum ivorense was moderate. The vital role of anti-oxidants is to neutralise the effect of free radicals which damage health cells. It also strengthens the immune system and prevent diseases (e.g. cardiovascular disease and cancer), thus imparting good health and longevity. Phenols help in providing the body defence against oxidative stress or damage arising from oxidising agents and free radicals particularly when the internal enzymatic mechanisms fail or become inadequate. Besides, they are known for their excellent ability to prevent fatty acids from oxidative decay.

\section{Conclusion}

It can be inferred from the phytochemical analysis that the bark of Erythrophleum ivorense can be said to have some medicinal potentials due to some phytochemicals present. But because high doses of the bark extract is an enormously strong, rapid acting cardiac poison, in warm blooded animals causing shortness of breath, seizures and cardiac arrest in a few minutes. It is advised that the bark be administered with caution despite it alkaloid content and high sodium level.

\section{CONFLICT OF INTEREST}

The authors declare that they have no conflict of interest.

\section{ACKNOWLEDGEMENT}

We want to appreciate the Laboratory Technologist of chemistry department, Mr. Aghogho, Delta State University for his assistance in the laboratory techniques for this work.

\section{REFERENCES}

Aigbokhan, E. I. (2014). Annotated Checklist of Vascular plants 
of Southern Nigeria- a quick reference guide to the vascular plants of Southern Nigeris: a systematic approach. University of Benin Press, Benin- City, 346p.

Amoah L.A., Agyare. C., Kisseh, E., Ayande P. G., \& Kwesi B.m (2014). Toxicity assessment of Erythrophleum ivirense and Parquetina nigrescens. Toxicology reports, (1), 411-420

AOAC (1990) Official Methods of Analysis. 15 ${ }^{\text {th }}$ Edition, Association of Analytical Chemists, Washington, DC, USA.

Bakarr, M. I., \& Janos, D. P. (1996). Mycorrhizal associations of tropical legume trees in Sierra Leone, West Africa. Forest Ecology and Management, 899(1-3), 89-92

Betti, J. L. (2004). An ethnobotanical study of medicinal plants among the Baka pygmies in the Dja biosphere reserves, Cameroon. African Study Monographs, 25(1), 1-27

Bosch, J., Bonjoch, J., \& Amat, M. (1996). The strychnos alkaloids. In: Cordell. G.A. (Editor). The Alkaloids 48. Academic Press, San Diego, United States, Pp. 75-189.

Burkill, H. M. (1985). The Useful Plants Africa of West Tropical Africa $2^{\text {nd }}$ Edition, Volume 1. Royal Botanic Gardens, Kew.

Diabate, M., Munive, A., Miana de Faria, S., Dreyfus, B., \& Galiana, A. (2005). Occurrence of modulation in unexplored leguminous trees native to the West African tropical rainforest and inoculation response of native species useful in reforestation. New Phytologist, 166(1), 231-239.

Einosho, O.A., \& Ayorinde A. (2008). Traditional Medicine in textbook of Medicinal Plants from Nigeria, University of Lagos press, 204p.

Gyamfi, M. A., \& Aniya Y. (2002).Antioxidant properties of Thonningianin $A$, isolated from the African medicinal herb, Thonningiasanguine. Biochemical Pharmacology, 63, 1725-37.

Harbone, J. B. (1973). Phytochemical methods: A guide to Modern Techniques of Plant Analysis. Chapman and Hall, London.

ITTO (2004). Annual review and assessment of the world timber situation, International Timber Trade Organization, Yokohma, Japan, 255p.

Noda, Y., Kneyuki, T., Igarashi, K., \& Packer, M. L. (2000). Antioxidant activity of nasunin, an anthocyanin in eggplant peels. Toxicology, 148, 119-123.

Obadoni, B. O., \& Ochuko, P.O. (2001). Phytochemical studies and comparative efficacy of the crude extracts of some homeostatic plants in Edo and Delta States of Nigeria. Global J. Pure Appl. Sci., 8, 203-208

Ogboru, R. O., Idibie C. A, Okolie P. L., \& Agboje I. (2016). Proximate and mineral element composition of the bark of Dacryodes edulis (G. Don) H.J. Lam. Research Journal for Chemical Sciences, 6(4), 2-16.

Ogboru, R. O., Okolie, P. L., \& Agboje, I. (2015). Phytochemical Screening and Medicinal Potentials of the Bark of Dacryodes edulis (G. Don) HJ Lam. Journal of Environmental and Analytical Chemistry. Doi: 10.4172/2380-2391.1000158.

Okeno, J.A., Chebet, D.K. and Mathenge, P.W (2003). Status of indigenous vegetables utilization in Kenya. Acta Horticulturae, 621, 95-100
Owoeye, E. A., Ogboru R. O., Agboje, I., \& Arabambi, I. D. (2016). Chemical composition and health potentials of the leaves of Treculia africana Decne. International Journal of Applied Research and Technology (IJRT). 5(6), 79-83.

Oyoyede, O.L. (2005). Chemical profile of unripe pulp of carica papaya. Pakistan Journal of Nutrition 496, 379-381.

Plants Resources for tropical Africa (PROTA) 11(2008). Medicinal Plants 1, 246-248

Prieto, P., Pineda, M., \& Angulilar, M. (1991). Spectrometric quantitation of antioxidant capacity through the formation of a phosphomolybdenum complex: specific application to the determination of Vitamin E. Analytical Biochem. Pp. 269-337

Richter, H. G., \& Dallwitz, M. J. (2000). Commercial timbers: descriptions, illustrations, identifications, and information. Retrieved from http://www.delta-intkey.com/wood/en /index.htm.

Sima, O. C., Ondo, J-P., Obame, E. L-C., Padyz, G-S., Zongo, C, Bongui, J-B., Nsi, E. E., \& Traore, A. (2016). Phytochemical screening and evaluation of antioxidant and antimicrobial properties of Erythrophleum ivorense A. Chev and Megaphrymium macrostachyum Benth. Medicinal plants from Gabon. International Journal of Biosciences. 8(6), 43-53.

Sofowora, A. (1993). Medicinal plants and Traditional medicine in Africa. 2nd Edition. Spectrum books Limited, Sunshine House, Ibadan, Nigeria, 289p.

Vernon, L. S, Orthofer, R, Lamuela-Raventos, R. M. (1999). Analysis of total phenols and other oxidation substrates and antioxidants by means of Folin- Ciocalteu reagent. Methods in Enzymology 299, 152-178.

Voorhoeve, A. G. (1979). Liberian high forest trees, A systematic botanical study of the 75 most important or frequent high forest trees, with numerous related species. Agricultural Research Reports 652, 2nd Impression. Center for Agricultural Publishing and Documentation, Wageningen, Netherlands. $416 p$.

WHO (2001). World Health Organization Legal Status of Traditional Medicine and Complimentary/ Alternative Medicine. A world wide review. WHO Publishing, 189. http://dx.doi.org/10.1016/S0076-6879(99)99017-1.

Zongo, C., Savadogo, A., Ouattara, L., Bassolé, I. H. N., Ouattara C. A. T., Ouattara A. S., Barro, N., Koudou, J., Traoré, A. S. (2010). Polyphenols content, antioxidant and antimicrobial activities of Ampelocissus grantii (Baker) Planch. (Vitaceae), a medicinal plant from Burkina Faso. International Journal of Pharmacology, 6(6), 880-887. 